\title{
Traditional management of ear, nose and throat (ENT) diseases in Central Kenya
}

\author{
Grace N Njoroge*1 and Rainer W Bussmann ${ }^{2}$
}

Address: ${ }^{1}$ Jomo Kenyatta University of Agriculture and Technology, Botany Department P.O. Box 62000, Nairobi, Kenya and ${ }^{2}$ University of Hawaii, Botany, 3860 Manoa Rd, Honolulu HI 96822, USA

Email: Grace N Njoroge* - gnjoroge@fsc.jkuat.ac.ke; Rainer W Bussmann - bussmann@hawaii.edu

* Corresponding author

Published: 27 December 2006

Journal of Ethnobiology and Ethnomedicine 2006, 2:54

This article is available from: http://www.ethnobiomed.com/content/2/I/54

(C) 2006 Njoroge and Bussmann; licensee BioMed Central Ltd.

This is an Open Access article distributed under the terms of the Creative Commons Attribution License (http://creativecommons.org/licenses/by/2.0), which permits unrestricted use, distribution, and reproduction in any medium, provided the original work is properly cited.

\begin{abstract}
Diseases of ear, nose and throat (ENT) often have serious consequences including hearing impairment, and emotional strain that lower the quality of life of patients. In Kenya, upper respiratory infections are among the most common infections encountered in outpatient facilities. Some of these infections are becoming difficult to control because some of the causing microorganisms have acquired antibiotic resistance and hence the need to develop new drugs with higher efficacy. Ethnobotanical studies have now been found to be instrumental in improving chances of discovering plants with antimicrobial activity in new drug development. In Kenya the majority of local people are turning to herbal remedies for primary health care needs. In most cases the sources of these remedies are undocumented and the knowledge about them passed orally form generation to generation, hence under threat of disappearing with current rates of modernisation.

This study explored the traditional remedies used in managing various ENT diseases in seven districts of the Central Province of Kenya. The most common ENT conditions managed using traditional therapies include: common cold, cough, tonsillitis, otitis-media, chest pains and asthma. The results indicate that 67 species belonging to 36 plant families were utilized in this region. These plants were of varying habits; herbs $(37.3 \%)$, shrubs $(34.4 \%)$, trees $(25.4 \%)$ as well as some grasses and sedges (3\%). The traditional preparations were found to be made mainly from leaves $(49 \%)$, roots (20.5\%) and barks (12.5\%). For each of the ENT conditions multiple species are utilized mainly as individual preparations but occasionally as polyherbal concoctions. In the case of common cold for example, 30 different species are used. Plants reported in this survey are important candidates for antimicrobial tests against ENT disease causing micro-organisms, especially those with antibiotic resistance.
\end{abstract}

\section{Background}

Diseases of the ear, nose and throat (ENT) affect the functioning of adults as well as children, often with significant impairment of the daily life of affected patients [1]. It has been envisaged that with increase in global population, infections remain the most important causes of disease, with upper respiratory infections causing hearing loss and learning disability particularly in children [2]. Ear infections such as chronic otitis-media have serious consequences in developing countries, such as retarded 
language development and progress in school among children $[3,4]$. Otitis-media, which is now known to be the most common childhood infection, leads annually to the death of over 50,000 children under 5 years [5]. In other cases nasal conditions may be distressing, as in the case of nasal myiasis/maggots in the nose [6].

In most countries in the developing world the number of otolaryngologists is negligible, while the problem is complicated by the fact that there is no training for public health otolaryngology and other ENT-related otolaryngology personnel $[2,4]$. This lack of trained personnel is of particular concern in African countries because the prevalence rates of some of the ENT disease such as chronic otitis-media is as high as $65 \%$ [7]. This problem as well as increased costs of conventional medicine has caused local people in Kenya and in other developing countries to seek treatment from traditional therapies.

Diseases of the ear, nose and throat can be caused by a variety of microorganisms. Rhinoviruses are the leading cause for common cold in all age groups for example, while enteroviruses are frequently associated [8]. Acute phryngitis/nosilitis is mainly associated with respiratory viruses, although bacteria, especially Streptococus spp. are found in some patients [9]. It has been shown that the nose is the main ecological niche where some of the drug resistant microorganisms like Staphylococcus aureus reside [10]. Although acute otitis-media is caused by bacteria the leading one being Streptococcus pneumoniae [11], viral infection are a predisposing factor for its development $[8,12]$. In communities that use antibiotics, Streptococcus pneumoniae rapidly acquire antibiotics resistance, often complicating this disease burden [11].

Tuberculosis is regarded as the oldest disease in man, affecting almost every organ of the body and causing about 2 million deaths annually [13]. Cases of tuberculosis are on the increase globally, with HIV/AIDS leading to re-emergence of extra pulmonary presentations [14]. While initial tuberculosis infections occur in the lungs, forms that occur for example in tonsils and the ear are now known to occur particularly in regions such as Africa where the disease is endemic [15].

Although antibiotics have contributed to the control of ENT infections, their over-use and misuse is now seen to cause an increase in antibiotic resistance [16]. Some of the chronic sinus ENT diseases resistant to current antibiotics include chronic middle ear infections, chronic sinus diseases, chronic coughs and recurrent pharyngo-tonsillitis [17]. Air pollution has been on the increase and is now known to directly affect the nose and the larynx causing inflammation, irritations and eventually infection. Even the ear is affected when the pollutants enter the mucosa of the tuba, causing impairment of the middle ear [18]. With increasing resistance of microorganisms associated with ENT infections and increasing environmental pollution, alternative sources for new drugs are necessary. These might be obtained from plants used in traditional medicines to control or treat these diseases. People in Kenya are now turning to the use of traditional herbal medicines so as to meet their primary healthcare needs [19].

In Kenya diseases of the respiratory tract are among the most common illnesses in outpatient clinics [20]. These diseases, combined with malaria, account for half the diseases reported in outpatient facilities [21]. Since some of the ENT disease causing microorganisms have become resistant to current antibiotics, there is need to investigate means of developing new, efficacious drugs.

Studies have now shown that ethobotanically-derived phytochemicals have greater activity than compounds derived from random screening and therefore a greater potential for products developed $[22,23]$. One study for example, has shown that $86 \%$ of plants species reported in Samoan pharmaceutical ethnopharmacopoeia showed pharmacological activity [24]. Further, many drugs in clinical use today were discovered from the way plants were used in traditional communities. Examples include quinine which, was discovered from the way traditional communities in S. America especially Peru, Columbia and Bolivia used plant species of the genus Cinchona in managing fevers [25]. Digitoxin on the other hand is a popular heart tonic obtained from Digitalis purpurea, a plant that was in use as heart tonic in traditional communities in Europe. Taxol is a modern therapy for ovarian cancer obtained from Taxus brevifolia which was a traditional medicinal plant in British Columbia [26].

This study investigated the diversity of traditional medicines used for the management of ear, nose and throat infections among the Kikuyus in Central Kenya with the aim of documenting plants that have potential for production of improved traditional medicines from local resources, as well as plants to be targeted for antimicrobial activity against microorganisms that cause ear, nose and throat infections especially those known to have developed antibiotic resistance.

\section{Materials and methods}

The Central Province of Kenya covers the area around Mount Kenya, where most of the Kikuyus live. The total population is estimated at 3,724,159 inhabitants in an area of $13,191 \mathrm{Km}^{2}$. The Kikuyus are the largest single ethnic group in Kenya and account for $21 \%$ of the country's population [27]. 
This study was part of a larger ethnobotanical survey involving over one hundred respondents, carried out for three years (2001-2004) among the Kikuyus of Central Kenya, comprising seven districts: Thika, Murang'a, Kiambu, Maragwa, Nyandarua, Kirinyaga and Nyeri (Figure 1). This study focuses on results from 64 respondents who used traditional therapies in management of ENT conditions for self medication or in treating others. Initial contacts were made with research assistants in all the districts to explain the aim of the research. These assistants were local people who knew the kikuyu language well, had lived in the area long enough and were familiar with the local people. Prior informed consent was sought with the respondents who were randomly selected in each area.

During the surveys semi-structured questionnaires were used to carry out the interviews, which targeted common ear, nose and throat infections known to the respondents, plant species used, parts used, methods of preparations as well as administration of the drugs. In some cases interviewees were accompanied in their plant collecting duties and observations made of the plants being collected. Where the respondents were uncomfortable with the questionnaires, discussions and informal interviews were employed and in the process information on traditional management of ENT infections obtained. During discussions, information on combination therapy or poly herbal management of ENT conditions were noted and recorded. Any use of none plant remedies for management of ENT infections were recorded.

Plants said to be useful in managing various ENT ailments during the interviews were visually identified in the field by the respondents. Voucher specimens were collected in duplicates using standard taxonomic procedures particularly recording important features for identification in the herbarium. Each specimen included vital parts such as leaves, stems, flowers, and fruits where available. For small herbaceous plants, whole plants were usually collected. For every specimen collected the vernacular names were also recorded. The specimens were dried in the herbarium and then mounted on sheets.

The collected plant material was identified at the Jomo Kenyatta University Herbarium, using the relevant local floras and other taxonomic literature [28-30]. Assistance in identification was sought from an experienced botanist (Mr Simon Mathenge) of the University of Nairobi Herbarium. The collections at Nairobi University Herbarium as well as Jomo Kenyatta University Herbarium were used to make comparisons with the identified specimens. To systematically collect data on management of ENT diseases in this region, questionnaires, semi-structured interviews, informal interviews and discussions with resource people were applied. Interviews were also supplemented by participant observations and consistent field walks to identify the medicinal plants cited and collect ethnotherapeautic specimens.

\section{Results and discussion}

This study found 67 species in 36 plant families as useful in management of ENT conditions in Central Kenya (Table 1) Of these, 24 species were cited three or more times during the field surveys. Some of the species with high frequency of mention included Eucalyptus saligna, Lippia javanica and Ocimum gratissimum (Figure 2). The highest proportion of species used was herbs (37.3\%), followed by shrubs $(34.3 \%)$ and trees $(25.4 \%)$. Sedges and grasses on the other hand comprised of $3 \%$ of the species used in ENT infections management in this region. Whiles one species would have different parts used; this study shows that most of the drug preparations were obtained from leaves (49\%) and reasonable amounts from barks $(12.5 \%)$ and roots $(20.5 \%)$. Harvesting plant medicines from barks is known to be the most destructive method of harvesting particularly because debarked trees rarely survive [31]. The trees and shrubs from which ENT concoctions are obtained from barks and roots are likely to be in danger of over-exploitation and their conservation status need further investigation.

The most cited ENT disease managed through traditional therapies was found to be the common cold (Figure 3). This condition which has several Kikuyu names (ikhuti, homa, njoma) is managed usually by use of individual species which are mainly boiled and administered by inhalation or leaves crushed and directly inhaled. In a few cases polyherbal preparations were noted especially the mixture of leaves of Ocimum bacilicum, O. gratissimum and lippia javanica which are boiled together and inhaled while the patient is covered with a thick piece of cloth such as a blanket.

Some studies have shown that viruses are associated with about two-thirds of the cases of common cold among children, while bacteria have been associated with about $4 \%$ of the cases. Among these viruses the leading ones are Rhinoviruses which cause common cold in all age groups but enteroviruses are also associated [8]. In the study area, about 30 plant species were found to be utilized for management of common cold. Extracts from these plants need to be a priority in testing for antimicrobial activity for further development of local drugs useful in management of colds.

The current study revealed that 13 plant species were used in managing Otitis media (Njika/burra, in Kikuyu) in Central Kenya (Table 1). Extracts from these plants need to be tested for their activity against some of these bacteria but also against viruses because viruses are known to be a pre- 


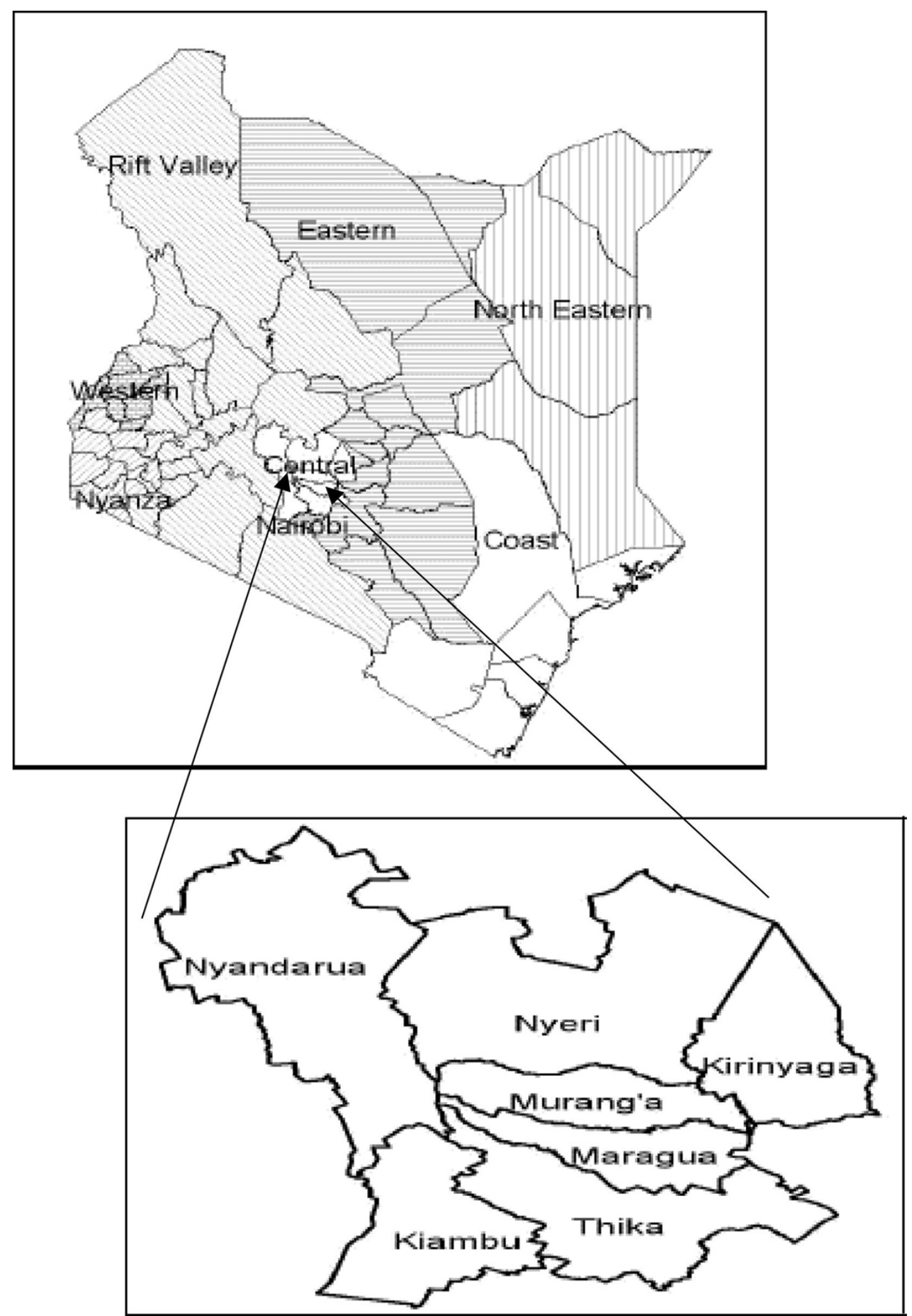

Figure I

Main provinces in Kenya and constituent districts where fieldwork was done. 
Table I: Diversity of plant species and methods used in management of ENT diseases in Central Kenya

\begin{tabular}{|c|c|c|c|c|c|c|}
\hline Species name & Family & Kikuyu name & Disease & Part used & $\begin{array}{l}\text { Method of drug } \\
\text { preparation }\end{array}$ & $\begin{array}{l}\text { Method of drug } \\
\text { administration }\end{array}$ \\
\hline $\begin{array}{l}\text { Acacia mellifera (Vahl) } \\
\text { Benth. }\end{array}$ & Mimosaceae & Mûthigira & WC & Bark & & Chewing \\
\hline $\begin{array}{l}\text { Acacia mellifera (Vahl) } \\
\text { Benth. }\end{array}$ & Mimosaceae & Mûthigira & $\mathrm{Cg}$ & Bark & Crushing & Chewing \\
\hline Ajuga remota Benth & Lamiaceae & Wanjirû wa rûriî & $\mathrm{CC}$ & Leaves & Boiling & Orally \\
\hline Ajuga remota Benth. & Lamiaceae & Wanjirû wa rûriî & $\mathrm{Cg}$ & Leaves & Boiling & Orally \\
\hline $\begin{array}{l}\text { Asparagus setaceus (Kunth) } \\
\text { Jessop }\end{array}$ & Asparagaceae & Karûrûra & $\mathrm{Cg}$ & Leaves & Crushing/pounding & Chewing \\
\hline Aspilia pluriseta Schweinf. & Asteraceae & Muutî & $\mathrm{Cg}$ & Bark & Crushing & Chewing \\
\hline Aspilia pluriseta Schweinf. & Asteraceae & Muutî & OM & Sap & Squeezed from stems & Directly installed \\
\hline Bidens pilosa $\mathrm{L}$. & Asteraceae & Mûcege & NB & Leaves & Boiling & Orally \\
\hline Caesalpinia volkensii Harms & Caesalpiniaceae & Mûbûthî & $\mathrm{CC}$ & Roots & $\begin{array}{l}\text { Crushing to release } \\
\text { sap }\end{array}$ & $\begin{array}{l}\text { Topically by rubbing } \\
\text { nasal region }\end{array}$ \\
\hline Carissa edulis Forssk. & Apocynaceae & Mûkawa & As & Roots Leaves & Boil & Orally \\
\hline Carissa edulis Forssk. & Apocynaceae & Mûkawa & $\mathrm{CP}$ & Roots & Boiling Soup added & Orally \\
\hline Carissa edulis Forssk. & Apocynaceae & Mûkawa & CC & Roots & Boiling & Orally \\
\hline $\begin{array}{l}\text { Citrus aurantiifolia } \\
\text { (Christm.) Swingle }\end{array}$ & Rutaceae & Ndimu & As & Fruit & Boiling & Orally \\
\hline $\begin{array}{l}\text { Citrus aurantiifolia } \\
\text { (Christm.) Swingle }\end{array}$ & Rutaceae & Ndimû & $\mathrm{CC}$ & Fruit & Boiling & Orally \\
\hline Clematis brachiata Thunb. & Ranunculaceae & Mûgaya ng'ûndu & $\mathrm{CC}$ & Leaves & $\begin{array}{l}\text { Boiling to release } \\
\text { steam }\end{array}$ & Inhalation of steam \\
\hline $\begin{array}{l}\text { Clutia abyssinica Jaub. \& } \\
\text { Spach }\end{array}$ & Euphorbiaceae & Mûthimambûri & To & Leaves & Boiling & Orally \\
\hline Coffea arabica L. & Rubiaceae & Kahûa/Mûhûa & $\mathrm{Cg}$ & Root & Boiling & Orally \\
\hline Colocasia antiquorum Schutt & Araceae & Kîrûtû & OM & Sap & Direct & Directly installed \\
\hline Combretum collinum Fres. & Combretaceae & Mûranjîkî & OM & Leaves & Sap extracted & Directly installed \\
\hline Crinum macawanii Bak. & Liliaceae & Gûtûngûrû kîa ngoma & As & Tuber & Boiling & Topically \\
\hline Crinum macawanii Bak. & Liliaceae & Gîtoka & OM & Leaves & Heated, sap squeeze & Directly installed \\
\hline Crinum macawanii Bak. & Liliaceae & Gîtûngûrû kîa ngoma & To & Bulb & Crushing & Massage \\
\hline $\begin{array}{l}\text { Crotalaria agatiflora } \\
\text { Schweinf. }\end{array}$ & Papilionaceae & Mûcingiri wa ngambainî & OM & Leaves & $\begin{array}{l}\text { Crushing, some water } \\
\text { added }\end{array}$ & Directly installed \\
\hline Croton megalocarpus Hutch. & Euphorbiaceae & Mûkindûri & $\mathrm{Cg}$ & Bark & Pounding & Chewing \\
\hline Croton megalocarpus Hutch. & Euphorbiaceae & Mûkindûri & To & Roots & Pounded & Chewing \\
\hline Cuscuta kilimanjari Oliv. & Convolvulaceae & Thîna & OM & Sap & Collected from stems & Directly installed \\
\hline Cussonia holstii Engl. & Araliaceae & Mûruruku & $\mathrm{Cg}$ & Bark & Pounding & Chewing \\
\hline Dalbergia lactea Vatke & Papilionaceae & Mwaritha & As & Wet leaves & $\begin{array}{l}\text { Crushed to release } \\
\text { sap }\end{array}$ & Topically \\
\hline Datura stramonium L. & Solanaceae & Ndatura & To & Stems & Crushing & Massage \\
\hline $\begin{array}{l}\text { Dombeya burgessiniae } \\
\text { Gerrard }\end{array}$ & Sterculiaceae & Mûkeû & $\mathrm{Cg}$ & Bark & Pounding & Chewing \\
\hline $\begin{array}{l}\text { Englerina woodfordioides } \\
\text { (Schweinf.) Balle }\end{array}$ & Loranthaceae & Kîeha & $\mathrm{CC}$ & Whole & Boiling & Orally \\
\hline Erythrina abyssinica DC. & Papilionaceae & Mûhûtî & $\mathrm{Cg}$ & Bark & Boiling & Orally \\
\hline Erythrina abyssinica DC. & Papilionaceae & Mûhûtî & NB & Bark & Boiling & Orally \\
\hline Eucalyptus saligna Smith & Myrtaceae & Mûbaû & $\mathrm{CC}$ & Leaves & Boiling & Inhalation of steam \\
\hline $\begin{array}{l}\text { Euphorbia joyae Bally \& S. } \\
\text { Carter }\end{array}$ & Euphorbiaceae & Kariaria & To & Stem & Boiling & Orally \\
\hline Juniperus procera Engl. & Cupressaceae & Mûtarakwa & $\mathrm{CC}$ & Bark & Boiling & Orally \\
\hline Kigelia africana (Lam.) & Bignoniaceae & Mûratina wa thûkûrîi & $\mathrm{CC}$ & Rhizome & Boiling & Orally \\
\hline \multicolumn{7}{|l|}{ Benth. } \\
\hline Kyllinga bulbosa P. Beau. & Cyperaceae & Ngothe & OM & Bulb & $\begin{array}{l}\text { Bulb crushed to } \\
\text { release sap }\end{array}$ & Directly installed \\
\hline Kyllinga bulbosa P. Beau. & Cyperaceae & Nyeki/Kîgombe & To & Leaves & Crushing & Chewing \\
\hline Lactuca inermis Forssk. & Asteraceae & Mûthûnga & To & Leaves & $\begin{array}{l}\text { Dry leaves in shade } \\
\text { and soak in hot water }\end{array}$ & Orally \\
\hline Lantana camara L. & Verbenaceae & Rûîthiki & $\mathrm{CC}$ & Leaves & $\begin{array}{l}\text { Crushing of wet } \\
\text { leaves }\end{array}$ & Inhalation \\
\hline Lantana camara L. & Verbenaceae & Mûkenia & OM & Leaves & Crushing & Directly installed \\
\hline
\end{tabular}


Table I: Diversity of plant species and methods used in management of ENT diseases in Central Kenya (Continued)

\begin{tabular}{|c|c|c|c|c|c|c|}
\hline $\begin{array}{l}\text { Lippia javanica (Burm.f.) } \\
\text { Spreng. }\end{array}$ & Verbenaceae & Mûthirîti & $\mathrm{CC}$ & Leaves & $\begin{array}{l}\text { Crushing, steeped in } \\
\text { hot water or milk }\end{array}$ & Orally \\
\hline Mangifera indica $\mathrm{L}$. & Anacardiaceae & Mwîembe & As & Leaves & Boil & Orally \\
\hline $\begin{array}{l}\text { Maytenus senegalensis } \\
\text { (Lam.) Exell }\end{array}$ & Celastraceae & Mûthuthi & To & Sap & Squeezed from stems & Topically \\
\hline Melia azadirachta L. & Meliaceae & Mûarubaine & To & Leaves & Boiling & Orally \\
\hline Melia azadirachta L. & Meliaceae & Mwarumbaine & $\mathrm{CC}$ & Leaves & Boiling & Orally \\
\hline $\begin{array}{l}\text { Momordica foetida } \\
\text { Schumach. }\end{array}$ & Cucurbitaceae & Karera & To & Leaves & Crushing & Chewing \\
\hline Ocimum basilicum L. & Lamiaceae & Mûtaa & $\mathrm{CC}$ & Leaves & $\begin{array}{l}\text { Crushed/Ground, } \\
\text { steeped in hot water } \\
\text { or milk }\end{array}$ & Orally \\
\hline Ocimum gratissimum $\mathrm{L}$. & Lamiaceae & Mûkandu & OM & Leaves & Crushed & Directly installed \\
\hline Ocotea usambarensis Engl. & Lauraceae & Mûthaitî & $\mathrm{CP}$ & Bark & Boiling & Orally \\
\hline Ocotea usambarensis Engl. & Lauraceae & Mûthaitî & $\mathrm{Cg}$ & Bark & Boiling & Orally \\
\hline $\begin{array}{l}\text { Osyris lanceolata Hocst \& } \\
\text { Stendel. }\end{array}$ & Santalaceae & Mûthaithi & $\mathrm{N} / \mathrm{T}$ & Leaves & Boiling & Orally \\
\hline Physalis peruviana $\mathrm{L}$. & Solanaceae & Mûnathi & As & leaves & Boiling & Orally \\
\hline $\begin{array}{l}\text { Piliostigma thonnigii } \\
\text { (Schumach.) Milne-Redh. }\end{array}$ & Papilionaceae & Mûkûra-ûtukû & $\mathrm{Cg}$ & Inner bark & Pounding & Chewing \\
\hline Piper capense L. & Piperaceae & Mûrûngû & $\mathrm{CC}$ & Leaves & Boiling & Orally \\
\hline Pistacia aethiopica Kokwaro & Anacardiaceae & Mûheheti & $\mathrm{CC}$ & Leaves & Boiling & Orally \\
\hline Plectranthus comosus Sims & Lamiaceae & Maigoya & OM & Leaves & Crushing & Directly installed \\
\hline Psidium guajava $\mathrm{L}$. & Myrtaceae & Mûbera & As & Leaves Dry & Boiling & Orally \\
\hline Psidium guajava $\mathrm{L}$. & Myrtaceae & Mûbera & $\mathrm{CC}$ & Leaves & Boiling & Orally \\
\hline $\begin{array}{l}\text { Pterolobium stellatum } \\
\text { (Forssk.) Brenan }\end{array}$ & Caesalpiniaceae & Mûtandambogo & $\mathrm{CC}$ & Roots & Boiling & Orally \\
\hline Rhamnus prinoides L'Herit & Rhamnaceae & Mûkarakinga & $\mathrm{CP}$ & Roots & Boiling Soup added & Orally \\
\hline Rhamnus prinoides L'Herit & Rhamnaceae & Mûkarakinga & $\mathrm{CC}$ & Leaves & Boiling & Orally \\
\hline Rhamnus prinoides L'Herit & Rhamnaceae & Mûkarakinga & To & Roots/Stem & Boiling & Orally \\
\hline Ricinus communis $\mathrm{L}$. & Euphorbiaceae & Mûbarîki & $\mathrm{Cg}$ & Seeds & $\begin{array}{l}\text { Grinding the seeds } \\
\text { and cooking the fatty } \\
\text { part }\end{array}$ & Orally \\
\hline Rubus apetalus Poir & Rosaceae & Mûtare & To & $\begin{array}{l}\text { Fruit and } \\
\text { leaves }\end{array}$ & Boiling & Orally \\
\hline $\begin{array}{l}\text { Sarcostemma viminale (L.) } \\
\text { R. Br. }\end{array}$ & Euphorbiaceae & Ndarû & OM & Stem & Heated, Sap squeezed & Directly installed \\
\hline $\begin{array}{l}\text { Schkuhria pinnata (Lam.) } \\
\text { Thell. }\end{array}$ & Asteraceae & Gakuinini & $\mathrm{CC}$ & Leaves & Boiling & Orally \\
\hline $\begin{array}{l}\text { Schkuhria pinnata (Lam.) } \\
\text { Thell. }\end{array}$ & Asteraceae & Gakuinini & $\mathrm{Cg}$ & Roots/Leaves & Boiling & Orally \\
\hline $\begin{array}{l}\text { Senna didymobotrya } \\
\text { (Fresen.) Irwin \& Barneby }\end{array}$ & Caesalpiniaceae & Mwenû & To & Leaves & Boiling & Orally \\
\hline Solanum aculeastrum Dunal & Solanaceae & Gîtûra & To & Root & Boiling & Orally \\
\hline Solanum anguivi Lam. & Solanaceae & Gatongu & OM & Fruits & Juice squeezed & Directly installed \\
\hline Sonchus oleraceus L. & Asteraceae & Mahiû & $\mathrm{CP}$ & Roots & Boiling Soup added & Orally \\
\hline Sonchus oleraceus L. & Asteraceae & Mahiû & To & Roots & Boiling & Orally \\
\hline $\begin{array}{l}\text { Sphilanthes mauritiania } \\
\text { (Pers.) DC. }\end{array}$ & Asteraceae & Gatharaita & $\mathrm{CC}$ & Flowers & Crushing & Chewing \\
\hline $\begin{array}{l}\text { Sporobolus pyramidalis } \mathrm{P} \text {. } \\
\text { Beauv. }\end{array}$ & Poaceae & Kagutu & $\mathrm{Cg}$ & Root & Boiling & Orally \\
\hline Tagetes minuta $\mathrm{L}$. & Asteraceae & Mûbangi & As & Leaves & Boiling & Orally \\
\hline $\begin{array}{l}\text { Tithonia diversifolia (Hemsl.) } \\
\text { A. Gray }\end{array}$ & Asteraceae & Marûrû & CC & Leaves & Boiling & Orally \\
\hline $\begin{array}{l}\text { Tithonia diversifolia (Hemsl.) } \\
\text { A. Gray }\end{array}$ & Asteraceae & Marûrû & $\mathrm{Cg}$ & Leaves/Roots & Boiling & Orally \\
\hline Toddalia asiatica (L.) Lam. & Rutaceae & Mûrûrûwe & $\mathrm{CC}$ & Roots & Boiling & Orally \\
\hline Toddalia asiatica (L.) Lam. & Rutaceae & Mûrûrûwe & $\mathrm{CC}$ & Roots & Boiling & Inhalation \\
\hline Toddalia asiatica (L.) Lam. & Rutaceae & Mûrûrûwe & $\mathrm{Cg}$ & Leaves & Boiling & Orally \\
\hline Urtica massaica Mildbr. & Urticaceae & Thabai & $\mathrm{CC}$ & Leaves & Boiling & Orally \\
\hline Vernonia lasiopus O.Hoffm. & Asteraceae & Mûchatha & $\mathrm{CC}$ & Leaves & Boiling & Orally \\
\hline Vernonia lasiopus O.Hoffm. & Asteraceae & Mûchatha & OM & Flowers & Sap squeezed & Directly installed \\
\hline $\begin{array}{l}\text { Warburgia ugandensis } \\
\text { Sprague }\end{array}$ & Canellaceae & Mûthîga & $\mathrm{CC}$ & $\begin{array}{l}\text { Bark and } \\
\text { leaves }\end{array}$ & Boiling & Orally \\
\hline
\end{tabular}


Table I: Diversity of plant species and methods used in management of ENT diseases in Central Kenya (Continued)

\begin{tabular}{|c|c|c|c|c|c|c|}
\hline $\begin{array}{l}\text { Withania somnifera (L.) } \\
\text { Dunal }\end{array}$ & Solanaceae & Mûrumbae & As & Roots & Boiling & Orally \\
\hline $\begin{array}{l}\text { Withania somnifera (L.) } \\
\text { Dunal }\end{array}$ & Solanaceae & Mûrumbae & CC & Leaves & Boiling & Orally \\
\hline $\begin{array}{l}\text { Zanthoxyllum usambarensis } \\
\text { (Engl.) Kokwaro }\end{array}$ & Rutaceae & Mwikunya & CC & Leaves & Boiling & Orally \\
\hline Zehneria scabra (L.f.) Sond. & Cucurbitaceae & Rwegethia & CC & Leaves & Boiling & Orally \\
\hline
\end{tabular}

Kikuyu names in brackets

As = Asthma (Githûri kinene, Acima, Gîkorora kia ngûkû)

$\mathrm{CC}=$ Common cold (Homa, Kihuti)

$\mathrm{Cg}=$ Cough (Ruhaya, Gîkorora)

$\mathrm{CP}=$ Chest Pains (Githûri)

$\mathrm{NB}=$ Nose bleeding

$N / T=$ Neck/throat (Ngingo)

OM = Otitis media (Njika, bûra)

To $=$ Tonsil (Ngaû)

WC $=$ Wooping cough (Gîkoroa thakame)

disposing factor for the development of acute otitis-media [11]. Lubricants from the industries and fat from chicken were also found to be installed into affected ears as a means of managing this condition. Further in some cases the queen stage of the termites were also found to be crushed and the resulting mixture installed in the affected ear(s). In a few cases the tail of the chameleon (alive) is also installed briefly into the affected ear(s). It is not clear whether this has any therapeutic value, but it is worth further investigation.

Otitis-media is known to be the most common bacterial infection especially among children. Sometimes it has severe complications, which have high economic impacts [11]. Studies in Kenya show that this disease causes sensori-neural hearing impairment among pre-school children, in addition to other complications [4]. On a global scale otitis-media is a major indication for antibiotic use with the consequence that some of the microorganisms associated with this condition have acquired antibiotic resistance as in the case of Pneumoccoci, Staphylococcus aureus, Hemophilus influenzae among others [2,10,11]. The traditional therapies cited in this study need to be screened to authenticate their use in managing this condition.

Sixteen plant species were used in managing tonsillitis in Central Kenya. In some of the cases the plant extracts were applied externally as in the case of the sap from Datura stramonium stems and bulb of Crinum macawanii. These plants are known to have analgesic properties [25] but their antimicrobial activity and those of the species that are either boiled or chewed need to be established. Respiratory viruses such as Adenoviruses, Epstein-Barr viruses,

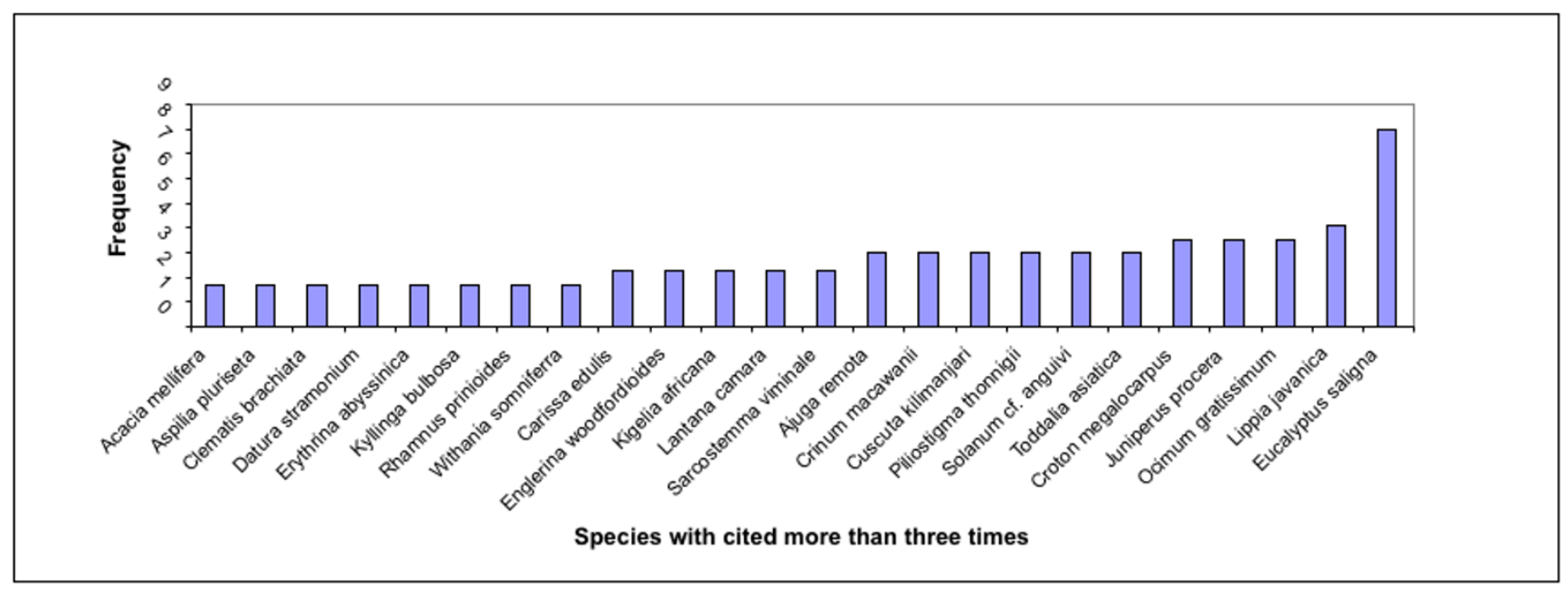

Figure 2

Frequency of plant species used in managing ENT diseases in Central Kenya. 


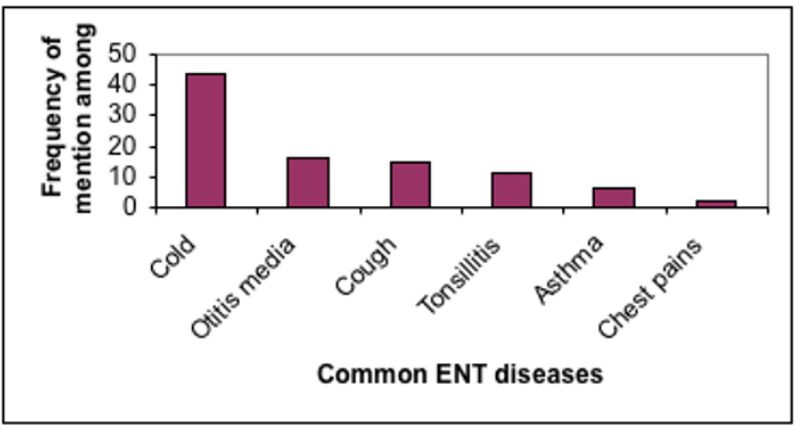

Figure 3

Frequency of ENT diseases managed by traditional herbal preparations.

influenza viruses and enteroviruses as well as bacteria are responsible for acute tonsillitis. Some of these for example, hemolytic Streptococci have already developed antibiotic resistance [8]. These microorganisms among others need to be the key targets for antimicrobial tests.

Asthma was one of the ENT allergic conditions traditionally managed using plant extracts in Central Kenya. The plants used in this case may be important sources of antiallergic preparations, which warrant further study.

\section{Conclusion}

This study revealed that the commonest ENT diseases managed through traditional therapies were common cold, Otitis media, cough, tonsillitis, asthma and chest pains. This research further revealed that 67 plant species are used in management of ENT infections in Central Kenya, while 24 of these species are mentioned three or more times during the field survey. There are also some none plant remedies such as fat, oils and animal parts cited in this study.

These remedies form an important database for bioassay guided identification and purification of important therapeutic compounds, antimicrobial trials on their efficacy and further development of improved traditional medicines or other new drugs for management of ENT infections. In the case of polyherbal preparations, their synergistic effects need further investigation. The study also reveals plants whose medicines are obtained in destructive manner and hence these species may need their conservation status to be investigated.

Since ethobotanically-derived phytochemicals have greater activity than compounds derived from random screening and therefore a greater potential for new drug products developed, it is expected that the results of this study will lead to pharmacological investigations with the plants showing reasonable antimicrobial activity.

\section{Acknowledgements}

The authors acknowledge financial support of BIOTA East Africa during the fieldwork. Technical support in identifying of plant specimens by Mr Simeon Mathenge of Nairobi University Herbarium is here acknowledged. We also thank all those people of Central Kenya who shared their information during the fieldwork surveys.

\section{References}

I. Witsell DL, Dolor RJ, Bolte JM, Stinnet SS: Exploring healthrelated quality of life in patients with diseases of the ear, nose and throat: A multicenter observation study. Otolaryngology - Head and neck Surgery 200I, I 25(4):.

2. Alberti PW: Pediatric ear, nose, and throat services' demands and resources: a global perspective. International Journal of Pediatrics Otorhinolaryngology 1999, 44(SuppI I): I-9.

3. WHO: Conquering suffering, Enriching humanity Wolrd Health Organization report, WHO, Geneva; 1997.

4. Newton EV, Macharia I, Mugwe P, Ototo B, Kan SW: Evaluation of the use of a questionnaire to detect hearing loss in Kenyan pre-school children. International Journal of Paediatric Otorhinolaryngology 200I, 57:229-234.

5. Rovers MM, de Kok IMCM, Schilder AGM: Risk factors for otitis media: An international perspective. International Journal of Paediatric Otorhinolaryngology 2006, 70: I 25 I-1256.

6. Kuruvilla G, Albert RRA, Anand J, Ranjith VT, Selvakumar P: Pneumocephalus: a rare complication of nasal myiasis. American Journal of Otolaryngology - Head and Neck Medicine and Surgery 2006, 27:133-135.

7. WHO/PDH: Prevention of hearing impairment from chronic Otitis media Report of WHO/CIBA Foundation workshop, Geneva; 1996. 19-21, November, 1996.

8. Nokso-Koivisto J, Hovi T, Pitkaranta A: Viral upper respiratory tract infections in young children with emphasis on acute otitis media. International Journal of Paediatric Otorhinolaryngology 2006, 70:1333-1342.

9. Esposito S, Blasi F, Bosis R, Droghetti N, Faelli A: Aetiology of acute pharyngitis: the role of atypical bacteria. Journal of Medical Microbiology 2004, 53:645-65I.

10. Wertheim HFL, Melles DC, Vos MC, van Leeuwen W, van Belkum A, Verbrugh HA, Nouwen JL: The role of nasal carriage in Staphylococcus aureus infections. Lancet infectious diseases 2005, 5:75I-762.

II. Malinoski FJ: Vaccines for otitis media and other paediatric pnuemococcal diseases. Therapeutic Strategies in press.

12. Williams JV, Tollefson SJ, Nair S, Chonmaitree T: Association of human metapneumovirus with acute otitis media. International Journal of Paediatric Otorhinolaryngology 2006, 70: I 189-1 I 93.

13. Nalini BMS, Vinayak SE: Tuberculosis in ear, nose and throat practise: its presentation and diagnosis. American Journal of Otolaryngology 2006, 27:39-45.

14. Miziara ID: Tuberculosis affecting the oral cavity in Brazilian HIV-infected patients. Oral Surg Oral Med Oral Pathol Oral Radiol Endod 2005, 100: 179-182.

15. Chavolla R, Dolci GF, Hernandez JFM, Ysunza A, Cuevas B, Lazos M, Solorio J: Primary tuberculosis of the tonsil. International Journal of Paediatric Otorhinolaryngology Extra 2006, I: I 50 - I53.

16. Bhattacharyya N, Shapiro J: Contemporary trends in microbiology and antibiotic resistance in otolaryngology. International Journal of Otolaryngology 2002, 29:59-63.

17. Megale SRMCL, Scanavini ABA, Andrade EC, Fernades MIM, Anselmo-Lima WT: Gastroesophageal reflux disease: Its importance in ear, nose, and throat practise. International journal of Paediatric Otorhinolaryngology 2006, 70:8I-88.

18. Foir R: Environmental ear, nose and throat problems in children. International Journal of Paediatric Otorhinolaryngology 1999, 49(Suppl):253-255.

19. Mboya TO: The department of standards and regulatory services: background information. Proceedings of the second national congress on quality improvement in health care, medical research and traditional medicine. Nov. 24-28th Nairobi, Kenya, 2003. 
20. Muga R, Kizito P, Mbayah M, Gakuruh T: Overview of health systems in Kenya. Nairobi, 2005.

21. Kenya National Human development report 1999.

22. Cox AP, Balick JM: Ethnobotanical Research and traditional Health Care in Developing Countries, plants, people and culture W.H. Freeman \& Co; 1996.

23. Flaster T: Ethnobotanical approaches to the discovery of bioactive compounds. In Progress in new crops: Proceedings of the third national symposium (56I-565) ASHS Press, Alexandria; 1996.

24. Figueiredo JN: Phytochemical studies on selected plants used in the Mozambican traditional medicine Inaguraldissertation, Universitat Basel; 1996.

25. van Wyk BV, Oudtshoorn BV, Gericke N: Medicinal plants of South Africa Briza publications, Pretoria; 2002.

26. Farnsworth NR: The role of ethnopharmacology in drug development. In Bioactive compounds from plants Edited by: Chadwick, Marsh. John Wiley \& Sons, New York; 1990.

27. Sindiga I, Kanunah MP, Aseka EM, Kiriga GW: Kikuyu traditional medicine. In Traditional medicine in Kenya Edited by: Sindiga I, Nyaigotti-Chacha C, Kanuna MP. East African Educational publishers, Nairobi; 1995.

28. ICRAF: $A$ selection of useful trees and shrubs for Kenya ICRAF, Nairobi; 1992.

29. Agnew ADQ: Upland Kenya wild flowers. In A flora of the ferns and herbaceous flowering plants of Upland Kenya Oxford University Press, London; 1994.

30. Beentje H: Kenya trees, Shrubs and lianas NMK, Nairobi; 1995.

31. Zschocke S, Rabe T, Taylor JLS, Jager AK, van Staden J: Plant part substitution - a way to conserve endangered medicnal plants? Journal of Ethnopharmacology 2000, 71 1:281-292.

\section{Publish with Bio Med Central and every scientist can read your work free of charge}

"BioMed Central will be the most significant development for disseminating the results of biomedical research in our lifetime. "

Sir Paul Nurse, Cancer Research UK

Your research papers will be:

- available free of charge to the entire biomedical community

- peer reviewed and published immediately upon acceptance

- cited in PubMed and archived on PubMed Central

- yours - you keep the copyright

Submit your manuscript here:

http://www.biomedcentral.com/info/publishing_adv.asp 